\title{
Variations in the natural density of European oak wood affect thermal degradation during thermal modification
}

\author{
Joël Hamada ${ }^{1}$ - Anélie Pétrissans ${ }^{1} \cdot$ Frédéric Mothe $^{2} \cdot$ Julien Ruelle $^{2} \cdot$ \\ Mathieu Pétrissans ${ }^{1}$ - Philippe Gérardin ${ }^{1}$
}

Received: 24 March 2015 / Accepted: 23 June 2015 / Published online: 16 July 2015

(C) INRA and Springer-Verlag France 2015

\begin{abstract}
- Key message Thermogravimetric analysis, performed on small samples of earlywood (EW) or latewood (LW), indicated that earlywood is more susceptible to thermal degradation than latewood. These results suggest a direct relationship between wood density (which depends on the $\mathrm{EW} / \mathrm{LW}$ ratio and indirectly on silviculture) and the response of wood during thermo-modification processes.

- Context One of the main difficulties in developing thermomodified wood products at an industrial scale lies in the difficulty of obtaining consistent products with a stable quality (durability, dimensional stability, color). This may be due
\end{abstract}

\section{Handling Editor: Jean-Michel Leban}

Contribution of the co-authors Joël Hamada, Frédéric Mothe, Julien Ruelle: carrying out the experiments, interpreting the results, and correction of the paper.

Mathieu Pétrissans: interpreting the results and correction of the paper. Anélie Pétrissans: co-designing and coordination of the $\mathrm{PhD}$ thesis, supervision of the work, interpreting the results, and writing the first draft of the paper.

Philippe Gérardin: co-designing and coordination of the $\mathrm{PhD}$ thesis, supervision of the work, interpreting the results, and writing the final draft of the paper.

Philippe Gérardin

philippe.gerardin@univ-lorraine.fr

1 Laboratoire d'Etudes et de Recherche sur le Matériau Bois, EA 4370-USC INRA, Faculté des Sciences et Technologies, Université de Lorraine, BP 70239, 54506 Vandoeuvre-lès-Nancy Cedex, France

2 Laboratoire d'Etude des Ressources Forêt Bois, UMR INRA-AgroParisTech 1092, INRA Centre de Nancy Lorraine, Route d'Amance, 54280 Champenoux, France either to the thermal treatment process itself or to inter- or intra-specific heterogeneity of wood properties.

- Aims We investigated the effect of the natural variability of oak wood, particularly in density, on the degree of thermodegradation during thermal treatments.

- Methods X-ray computed tomography was used to assess the effect of initial wood density of oak boards on their thermo-degradation. Intra-ring wood density was estimated using thermogravimetric analysis and microdensitometry.

- Results X-ray CT did not allow establishment of a clear correlation between initial wood density and mass loss due to thermo-degradation, while thermogravimetric analysis, performed separately on earlywood and latewood samples, revealed a larger susceptibility to thermal degradation of the less dense earlywood samples compared to more dense latewood samples

- Conclusion Initial wood density, which is directly controlled by the earlywood/latewood ratio modulated by silvicultural practices, directly influences thermo-degradation during thermal treatment. Initial wood density therefore appears to be a potential parameter influencing industrial thermal treatment processes.

Keywords Density · Earlywood · Thermal treatment . Latewood · Oak · Ring $\cdot$ Thermogravimetric analysis · Variability $\cdot \mathrm{X}$-ray CT

\section{Introduction}

Interest in the use of wood as building material is growing due to woods' intrinsic technological properties and its ability to reduce greenhouse gas emissions. However, exposed to outdoor conditions, unprotected wood undergoes degradation 
due to several biotic or abiotic agents. Biocidal treatments allow protecting wood from degradation; however, their utilization has grown to be controversial because of their toxicity. Environmental pressure in France and in most European countries during the last decade has lead to the development of more environmentally acceptable protection methods. In this context, thermal modification processes are an attractive alternative to classical wood preservation methods for some applications. Wood thermal treatment improves some properties of the material such as its durability to decay (Hakkou et al. 2006; Guller 2012) and its dimensional stability (Mouras et al. 2002). The influence of treatment conditions on chemical composition and conferred properties of thermally modified wood have been intensively investigated. Previous studies have shown that new properties conferred to thermally modified wood are directly related to thermal treatment intensity, which depends directly on duration and treatment temperature (Nguila Inari et al. 2009; Šušteršic et al. 2010). These findings have resulted in the development of a quality control marker for thermally modified wood based on mass loss (ML). Producing final products with constant quality (durability, dimensional stability, color) on an industrial scale is a challenge. These difficulties can be attributed to either the thermal treatment processes themselves or to the inter- and intra-species wood heterogeneity. Inter-species property differences including parameters such as chemical composition and density have been reported to strongly influence degradation reactions occurring during thermal treatment and consequently the final properties of the material (Chaouch et al. 2010; Candelier et al. 2011). Thus, hardwoods are generally more sensitive to thermal degradation than softwoods, while woods with high densities seem to be more sensitive to thermal degradation than less dense woods (Chaouch et al. 2010). Relative to intra-species differences, wood quality of European oak is reported to be deeply influenced by ring width depending on ecological factors, soil quality, forest management, tree age, and genetics (Bouriaud et al. 2004; Zhang et al. 1993; Knapic et al. 2007; Bergès et al. 2008). In this context, wood density is often used as a functional trait in tree ecology to evaluate wood quality. Wood quality of ring porous species has been reported to be strongly correlated to growth rate which influences the ring's width and density (Polge and Keller 1973). Differences between earlywood (EW) and latewood (LW) properties contribute to changes in timber dimensional stability (Kretschmann and Cramer 2007). Furthermore, differences in the chemical composition between EW and LW exist (Kibblewhite et al. 2010), which may influence their thermal degradation kinetic. Recently, Shchupakivskyy et al. (2014) have described a higher susceptibility of oak's EW to thermal degradation comparatively to its LW using high-frequency densitometry.

The aim of this study was to assess initial intrinsic wood properties including density and the EW/LW ratio of the wood and determine how this may impact the thermal degradation of wood and the properties conferred to the final material. A better understanding of the effect of initial wood quality on thermal degradation reactions is postulated, and research in this area may aid in the better utilization of wood in industrial thermal treatment processes to improve the competitiveness of the wood forestry sector. Two approaches were used: (1) Xray computed tomography (CT) was used to assess the initial density of oak boards before and after heat treatment, and (2) $\mathrm{X}$-ray micro-densitometry and thermogravimetric analysis (TGA) were used to measure the pre- and post-treatment thermal stability of EW versus LW.

\section{Material and methods}

\subsection{Materials}

Oak heartwood was chosen in this study because of the availability of prior sampling data on wood quality as related to tree origin (Guilley and Nepveu 2003; Guilley et al. 2004). Ten radially cut European oak boards (Quercus petraea Liebl), $250 \times 110 \times 25 \mathrm{~mm}^{3}(L \times R \times T)$, were used for the X-ray CT study. Five trees $(2385,2388,2390,2487,2492)$ previously studied to assess the influence of site quality, silviculture, and region on wood density (Guilley and Nepveu 2003; Guilley et al. 2004) were chosen to provide boards of different initial densities (Table 1). Two pieces from the same tree were used: one close to the pith (inner heartwood) identified as "IHW" and one close to the sapwood (outer heartwood) identified as "OHW". "OHW/SW" was used to identify board 2390 containing heartwood and sapwood. X-ray micro-densitometry and thermogravimetric analysis was performed on two trees (2390 and 2547) issued from distinct French stands (Guilley et al. 2004) presenting different densities, mean ring width, crown base height, and silvicultural history (Table 2). The separation of EW and latewood LW was performed only for the 20 rings between the 15th and the 50th annual ring, as these were some of the largest rings and they provided a good opportunity to assess the ring density without potential overlap with other rings. A microtome knife and hammer were used to separate EW from LW. Samples of EW were mixed together and milled using a Retsch MM 200 (Haan, Germany) to $<0.160 \mathrm{~mm}$, before drying at $103{ }^{\circ} \mathrm{C}$. The same procedure was applied for LW samples. Combined EW and LW samples were also assessed using the same procedures.

\subsection{X-ray computed tomography}

Densities of oak boards were determined before and after thermal treatment by X-ray CT using a General Electric Bright Speed Excel 4 apparatus. The 3D images were used to plot a density map for each board before and after curing 
Table 1 Classification of wood origins, age, initial density, and mass loss

\begin{tabular}{|c|c|c|c|c|c|c|c|c|}
\hline \multirow[t]{2}{*}{ Sample } & \multirow{2}{*}{$\begin{array}{l}\text { Stand } \\
\text { (regions) }\end{array}$} & \multirow{2}{*}{$\begin{array}{l}\text { Forest } \\
\text { management }\end{array}$} & \multirow[t]{2}{*}{ Age (year) } & \multirow{2}{*}{$\begin{array}{l}\text { Average ring } \\
\text { size }(\mathrm{mm})\end{array}$} & \multirow{2}{*}{$\begin{array}{l}\text { Initial density } \\
\left(\mathrm{kg} / \mathrm{m}^{3}\right)\end{array}$} & \multirow{2}{*}{$\begin{array}{l}\text { Final density } \\
\left(\mathrm{kg} / \mathrm{m}^{3}\right)\end{array}$} & \multicolumn{2}{|c|}{ ML (\%) } \\
\hline & & & & & & & Meas. & Calc. \\
\hline 2385 IHW & Alsace & Coppice & 181 & 1.81 & $611 \pm 64$ & $564 \pm 54$ & 10.6 & 9.4 \\
\hline 2385 OHW & Alsace & Coppice & 181 & 1.81 & $516 \pm 54$ & $472 \pm 50$ & 12.6 & 11.0 \\
\hline 2388 IHW & Alsace & Even-aged & 143 & 1.84 & $663 \pm 62$ & $617 \pm 58$ & 12.0 & 10.4 \\
\hline 2388 OHW & Alsace & Even-aged & 143 & 1.84 & $631 \pm 79$ & $582 \pm 74$ & 13.2 & 11.1 \\
\hline 2492 IHW & Normandie & Coppice & 181 & 2.98 & $698 \pm 92$ & $641 \pm 92$ & 12.4 & 10.9 \\
\hline 2492 OHW & Normandie & Coppice & 181 & 2.98 & $651 \pm 86$ & $606 \pm 85$ & 12.2 & 10.5 \\
\hline 2487 IHW & Center & Coppice & 149 & 2.25 & $602 \pm 88$ & $575 \pm 84$ & 10.1 & 7.7 \\
\hline 2487 OHW & Center & Coppice & 149 & 2.25 & $536 \pm 84$ & $496 \pm 75$ & 12.8 & 11.4 \\
\hline 2390 OHW & Alsace & Even-aged & 171 & 2.19 & $623 \pm 75$ & $575 \pm 68$ & 7.2 & 5.3 \\
\hline $2390 \mathrm{OHW} / \mathrm{SW}$ & Alsace & Even-aged & 171 & 2.19 & $507 \pm 77$ & $476 \pm 69$ & 9.8 & 7.9 \\
\hline
\end{tabular}

using a calibration method described by Freyburger et al. (2009). Each board was virtually sliced into 1,000 cubic volumes $(20 \mathrm{~L} \times 10 \mathrm{R} \times 5 \mathrm{~T})$ leading to a 1,000-point cartography image. Every cubic volume is an image of $512 \times 512$ pixels whatever the size of the field of vision. In the maximal magnification, the field diameter is approximately of $10 \mathrm{~cm}$ giving a pixel size around $200 \mu \mathrm{m}$. In our experiments, pixel size was fixed to $300 \mu \mathrm{m}$, approximately. ML and density variation were calculated using a dedicated plugin for the image processing software ImageJ (Schneider et al. 2012) and a script for the statistical software R (R Core Team 2014).

\subsection{X-ray micro-densitometry}

Radial density variation of wood was characterized by X-ray micro-densitometry using a microfocus $\mathrm{X}$-ray source (Hamamatsu L9181-02 $130 \mathrm{kV}$ ) and a digital X-ray detector (Varian PaxScan 4030R). Radial profiles of wood density of the samples were computed from the radiographies using the Cerd software suite (Mothe et al. 1998a, b).

\subsection{Board thermal treatment}

Wood specimens were oven-dried at $103{ }^{\circ} \mathrm{C}$ for $48 \mathrm{~h}$ before thermal treatment. Thermal treatment was performed under nitrogen by conduction by placing wood samples between two metallic heating plates in an oven on a precision balance to assess ML continuously during heating (Chaouch et al.
2010). Treatment occurred in stages starting initially at $103{ }^{\circ} \mathrm{C}$ until mass stabilization, followed by $1 \mathrm{~h}$ at $170{ }^{\circ} \mathrm{C}$, and then $2 \mathrm{~h}$ at $220^{\circ} \mathrm{C}$. The heating rate and gas flow were $1{ }^{\circ} \mathrm{C} \mathrm{min}^{-1}$ and $120 \mathrm{~mL} \mathrm{~min}^{-1}$, respectively. The ML due to thermal degradation was calculated according to the formula:

$\operatorname{ML}(\%)=100 \times\left(m_{0}-m_{1}\right) / m_{0}$

where $m_{0}$ is the initial dry mass of the sample before thermal treatment and $m_{1}$ the oven-dried mass of the same sample after thermal treatment.

\subsection{Thermogravimetric analysis}

Thermogravimetric analysis was performed on 10-mg samples of EW or LW under nitrogen using a Mettler Toledo TGA/DSC STAR ${ }^{\mathrm{e}}$ system. After drying at $103{ }^{\circ} \mathrm{C}$, experiments were performed at $220{ }^{\circ} \mathrm{C}$ for $2 \mathrm{~h}$. The heating rate and gas flow were, respectively, $10 \mathrm{~K} \mathrm{~m}^{-1}$ and $50 \mathrm{~mL} \min ^{-1}$. The thermal behavior of EW and LW samples issued from the heartwood of trees 2390 and 2547 was analyzed separately on sample, and five replicates of experiments were carried out for each sample.

\subsection{Determination of chemical composition}

All analyses for extractives, holocellulose, and Klason lignin content were adapted from literature procedures with minor modifications (Rowell et al. 2005).

Table 2 Averaged wood density according to wood compartments

\begin{tabular}{llllllll}
\hline Sample & Stand (regions) & $\begin{array}{l}\text { Forest } \\
\text { management }\end{array}$ & Age (year) & $\begin{array}{l}\text { Averaged ring } \\
\text { size }(\mathrm{mm})\end{array}$ & $\begin{array}{l}\text { Averaged ring } \\
\text { density }\left(\mathrm{kg} / \mathrm{m}^{3}\right)\end{array}$ & $\begin{array}{l}\text { Averaged earlywood } \\
\text { density }\left(\mathrm{kg} / \mathrm{m}^{3}\right)\end{array}$ & $\begin{array}{l}\text { Averaged latewood } \\
\text { density }\left(\mathrm{kg} / \mathrm{m}^{3}\right)\end{array}$ \\
\hline 2390 & Alsace & Even-aged & 171 & 2.19 & 744.10 & 633.27 & 802.98 \\
2547 & Lorraine & Coppice & 147 & 3.12 & 700.66 & 582.94 & 768.62 \\
\hline
\end{tabular}




\subsubsection{Extractive content}

EW or LW was ground to obtain particles ranging between 0.2 and $0.4 \mathrm{~mm}$. This material was successively extracted in a Soxhlet extractor with a toluene/ethanol $(2: 1, v / v)$ mixture $(6 \mathrm{~h})$, followed by ethanol $(6 \mathrm{~h})$ and dried at $103{ }^{\circ} \mathrm{C}$ for $48 \mathrm{~h}$. After extraction, organic solvents were evaporated under vacuum using a rotary evaporator. Crude extracts were stored in desiccators under vacuum for final drying and weighed to determine extractive content based on moisture-free wood powder.

\subsubsection{Holocellulose content}

Of the ground wood, $500 \mathrm{mg}$ was placed in a $250-\mathrm{mL}$ flask containing $30 \mathrm{~mL}$ of distilled water and heated at $75{ }^{\circ} \mathrm{C}$. Acetic acid $(0.1 \mathrm{~mL})$ and $15 \%$ aqueous sodium chlorite $(2 \mathrm{~mL})$ were then added each hour for $7 \mathrm{~h}$. The mixture was filtered on a Büchner funnel and the residue washed with water, Soxhlet extracted for $2 \mathrm{~h}$ with ethanol, and dried at $103{ }^{\circ} \mathrm{C}$ to a constant mass.

\subsubsection{Klason lignin content}

One hundred seventy-five milligrams of the ground wood was mixed with $72 \% \mathrm{H}_{2} \mathrm{SO}_{4}(10 \mathrm{~mL})$ for $4 \mathrm{~h}$ at room temperature. The mixture was then diluted with $42 \mathrm{~mL}$ of distilled water, refluxed for $4 \mathrm{~h}$, and filtered. The Klason lignin thus obtained was washed with hot water and dried at $103{ }^{\circ} \mathrm{C}$ to a constant weight. The different filtrates were carefully transferred to a 1$\mathrm{L}$ volumetric flask, rinsed with distilled water, and made up to a 1-L total volume for further monosaccharide content determination.

\subsubsection{Monosaccharide content}

Separation and quantification of simple sugars were performed using a Dionex ICS-3000 system consisting of an SP gradient pump, an AS autosampler, an ED electrochemical detector with a gold working electrode, an $\mathrm{Ag} / \mathrm{AgCl}$ reference electrode, and Chromeleon version 6.8 (Dionex Corp., USA) software. A Carbopac PA1 $(4 \times 250 \mathrm{~mm}$, Dionex $)$ column with a guard column $(4 \times 50 \mathrm{~mm}$, Dionex $)$ was used as a stationary phase using isocratic conditions with $1 \mathrm{mM}$ sodium hydroxide as the eluent. Eluents were prepared by dilution of a $46-48 \%$ $\mathrm{NaOH}$ solution (PA S/4930/05 Fisher Scientific) in ultrapure water. All eluents were degassed before use by flushing with helium for $20 \mathrm{~min}$; subsequently, they were kept under a constant helium pressure (eluent degassing module, Dionex). After each run, the column was washed for $10 \mathrm{~min}$ with $200 \mathrm{mM} \mathrm{NaOH}$ solution and equilibrated for $15 \mathrm{~min}$ to the initial conditions. Samples of monosaccharides were injected using a $25-\mu \mathrm{L}$ full loop, and separations were performed at
$25{ }^{\circ} \mathrm{C}$ at a rate of $1 \mathrm{~mL} / \mathrm{min}$. The pulse sequence for pulsed amperometric detection consisted of a potential of $+100 \mathrm{mV}$ (0-200 ms), +100 mV integration (200-400 ms), -2,000 mV (410-420 ms), +600 mV (430 ms), and - $100 \mathrm{mV}(440-$ $500 \mathrm{~ms})$.

\section{Results}

\subsection{Macroscopic approach}

Results concerning initial and final densities measured by Xray computed tomography, measured and calculated from Xray $\mathrm{CT}$ data mass losses after thermo-modification, and information concerning wood characteristics according to previous studies (Guilley et al. 2004) are listed in Table 1.

For all trees studied, samples withdrawn from the internal heartwood area present higher density than the samples obtained from the outer heartwood/sapwood region of the same tree. This difference is very pronounced for trees coming from coppice forest management (trees 2385, 2487, and 2,492). For the tree 2388, issued from even-aged management, the density difference is lower. Averaged values of density measured by X-ray CT before and after thermal treatment indicated a reduction of wood density in all cases after thermal modification. Figure 1 presents box plots and the statistical data of density variation of wood boards after thermal treatment.

Median density variation values are comprised between 25 and $50 \mathrm{~kg} / \mathrm{m}^{3}$ with a mean value of $43 \mathrm{~kg} / \mathrm{m}^{3}$ representing a decrease of approximately $7 \%$ of the initial mass of the board. Behavior of wood boards obtained from the same tree shows that, in some cases, higher dense samples which constituted mainly of internal heartwood give a slightly higher density variation compared to the less dense samples issued from the external heartwood to sapwood zone (trees 2385 and 2492). Tree 2487 behaves differently; higher density inner heartwood

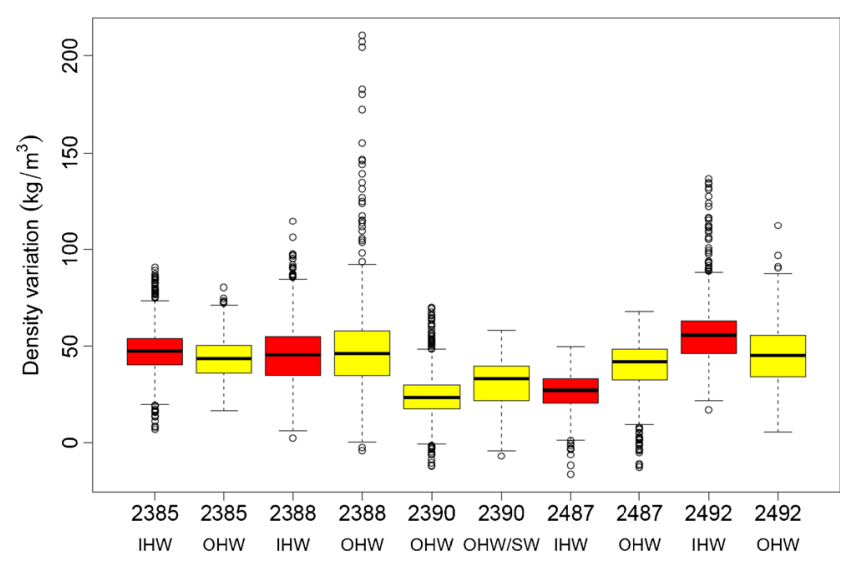

Fig. 1 Density variation of oak boards after thermal treatment measured using X-ray CT 
presents weaker density variation after thermal treatment than lower density outer heartwood. Anyway, no obvious relation was found between the initial wood density and thermodegradation level estimated through density variation after thermal treatment (Table 1).

Figure 2 represents box plots of mass losses according to the different boards studied.

No clear relationships between mass losses resulting from wood thermo-degradation and wood origin can be established. Figure 3 represents evolution of all mass losses determined from board density map versus initial density distribution.

Results highlight strong density variability inside a same board with an important dispersion of mass loss values for a given initial densities. Indeed, samples with a similar initial density can lead to different mass losses, while, at the same time, samples presenting similar mass loss can result from different initial density samples.

Finally, the mass loss distribution, averaged for all the boards depicted in Table 1, according to longitudinal, radial, and tangential directions, has been investigated using X-ray CT data and presented in Fig. 5.

It can be observed that mass loss was lower on the board's edges and higher in the core indicating different temperature conditions during the treatment process. These results may be explained by the exothermicity of thermo-degradation reactions explaining the higher temperature in the core compared to the edges resulting locally in a higher degradation of wood (Pétrissans et al. 2014).

\subsection{Intra-ring approach}

Variation of oak wood density along the radial direction according to the annual ring width was investigated to evaluate the effect EW/LW ratio on wood thermal stability using thermogravimetric analysis. Figure 6 describes the ring width and the ring density according to ring age.

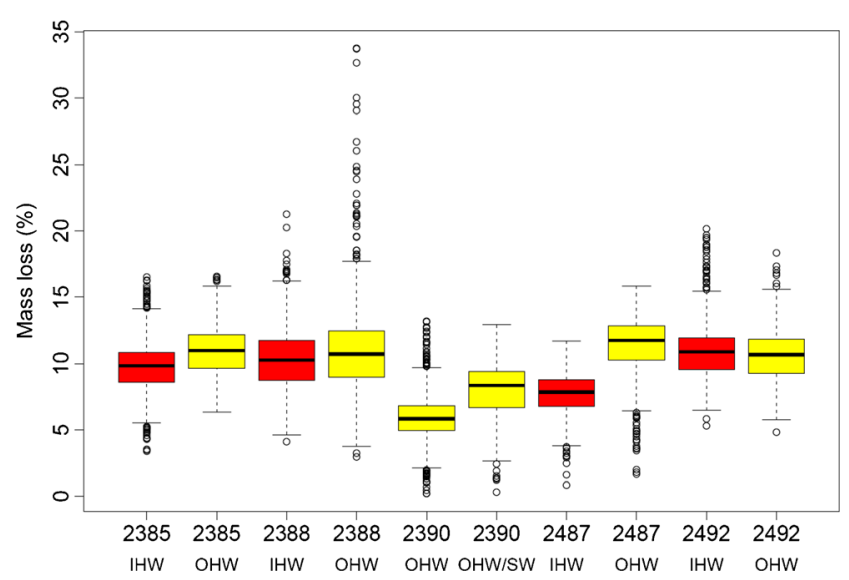

Fig. 2 Mass loss of oak boards after thermal treatment measured using $\mathrm{X}$-ray CT

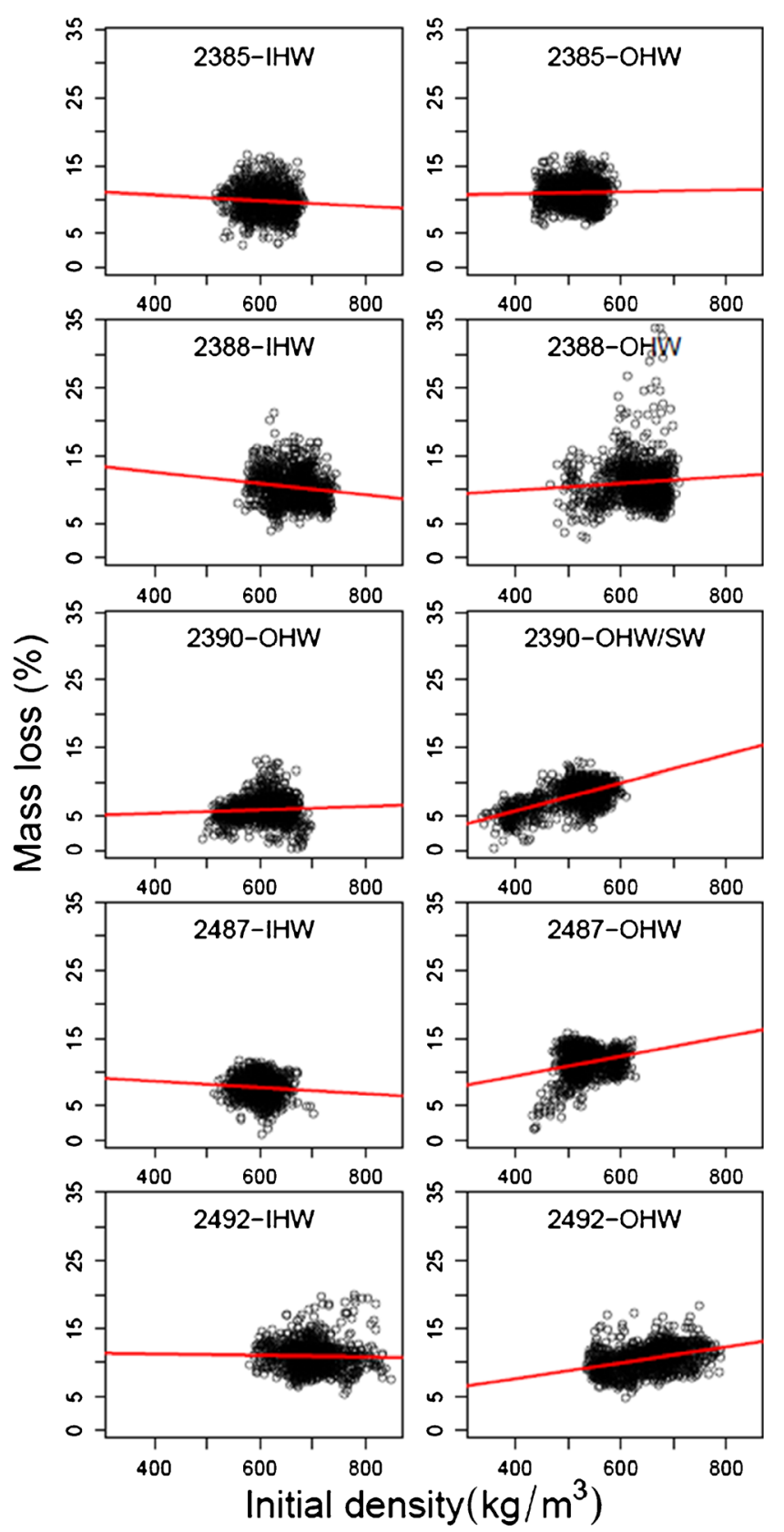

Fig. 3 Individual mass losses versus local densities recorded using $\mathrm{X}$-ray CT

Strong variations of density exist locally according to ring age and width corroborating the density dispersion recorded using X-ray CT. For both trees, wood density tends to decrease with ring age, while ring width increases in a first time to become more or less constant in a second time. Table 2 and Fig. 7 describe density variations according to earlywood or latewood compartments.

In all cases, earlywood presents lower density compared to latewood. Thermal behavior of earlywood and latewood samples was then evaluated. Table 3 indicates chemical composition and the weight losses recorded by TGA for the different 
Table 3 Chemical composition and weight loss recorded by thermogravimetric analysis

\begin{tabular}{lllll}
\hline Sample & $\begin{array}{l}\text { Extract } \\
(\%)\end{array}$ & $\begin{array}{l}\text { Lignin } \\
(\%)\end{array}$ & $\begin{array}{l}\text { Holocellulose } \\
(\%)\end{array}$ & $\begin{array}{l}\text { WL } \\
(\%)\end{array}$ \\
\hline $2390 \mathrm{EW}$ & 1.1 & 27 & 72 & $12.44 \pm 0.32$ \\
$2390 \mathrm{LW}$ & 1.5 & 27 & 73 & $11.13 \pm 0.15$ \\
$2547 \mathrm{EW}$ & 0.7 & 28 & 72 & $11.64 \pm 0.38$ \\
$2547 \mathrm{LW}$ & 1.3 & 24 & 76 & $11.11 \pm 0.20$ \\
\hline
\end{tabular}

samples of earlywood and latewood of trees 2390 and 2547, while Table 4 reported monosaccharide content of earlywood and latewood, respectively.

Results show a clear difference in the thermal behavior of the earlywood and latewood compartments, earlywood being more sensitive to thermal degradation than latewood. Monosaccharide content indicates also clear differences between earlywood and latewood, especially, concerning their glucose content, which is higher in latewood compartment.

\section{Discussion}

\subsection{Macroscopic approach}

In a general manner, no obvious relation was observed between the initial measured wood density and thermodegradation level estimated through density variation after thermal treatment using X-ray CT or gravimetric measures (Fig. 1). Mass losses estimated from X-ray computed tomography images were compared to those obtained after thermomodification by weighing (Table 1). A difference of about $\pm 2 \%$ was noticed between measured and calculated mass losses. This difference may be explained by the principle of mass loss determination using X-ray CT. Indeed, computed tomography measures precisely density distribution and dimensions of the sample, while sample's mass is estimated. This estimation may be at the origin of the difference observed between X-ray CT and gravimetric measurements.

Independently, of the initial wood density, it is difficult to establish a clear relationship between the effect of thermo- degradation reactions and density evolution after thermal treatment (Fig. 2). Even if initial sample densities are quite different, with averaged densities ranging from 550 to $700 \mathrm{~kg} /$ $\mathrm{m}^{3}$, the averaged mass losses are relatively similar (10 to $12 \%$ ) showing again no clear relationship between initial wood density and wood's susceptibility to thermo-degradation. These results differ slightly from previously reported results on the effect of wood species on its susceptibility to thermo-degradation indicating that higher density wood species were generally more sensitive to heat than less dense wood species (Chaouch et al. 2010).

In order to go further into the results, all mass losses determined for board cartography were plotted versus initial density distribution (Fig. 3). Results highlight strong density variability inside a similar board with an important dispersion of mass losses for a given initial density. Behavior of each individual board indicated strong density variability inside the board with an important dispersion of mass losses for given initial densities. Points with similar initial density lead to more or less important mass losses, while points with similar mass loss can be obtained from different initial density samples. Again, no obvious relation can be determined between initial density and thermo-degradation. The only conclusion that can be made from the different graphs plotted in Fig. 3 concerns the different behavior of heartwood and sapwood when both are present in the same board. Indeed, representation of the points according to their localization in the board of sample $2390 \mathrm{OHW} / \mathrm{SW}$ clearly indicated two clusters of points corresponding to heartwood and sapwood (Fig. 4).

Lower density sapwood was less susceptible to thermodegradation than higher density heartwood. This behavior may be due either to a difference of chemical composition between sapwood and heartwood or to a lower heat transfer in sapwood comparatively to heartwood due to its lower density.

Averaged mass loss distribution according to longitudinal, radial, and tangential directions of the board has been investigated using X-ray CT (Fig. 5). Results indicated that sample position in the board influences more or less thermal degradation processes. Indeed, it can be observed that mass loss was lower on the board's edges and higher in the core indicating different temperature conditions during the treatment process. These results may be explained by the exothermicity of

Table 4 Monosaccharide content (mg/L)

\begin{tabular}{lllllllll}
\hline Sample & $\begin{array}{l}\text { Rhamnose } \\
\mathrm{mg} \mathrm{L}^{-1}\end{array}$ & $\begin{array}{l}\text { Arabinose } \\
\mathrm{mg} \mathrm{L}^{-1}\end{array}$ & $\begin{array}{l}\text { Galactose } \\
\mathrm{mg} \mathrm{L}^{-1}\end{array}$ & $\begin{array}{l}\text { Glucose } \\
\mathrm{mg} \mathrm{L}^{-1}\end{array}$ & $\begin{array}{l}\text { Xylose } \\
\mathrm{mg} \mathrm{L}^{-1}\end{array}$ & $\begin{array}{l}\text { Mannose } \\
\mathrm{mg} \mathrm{L}^{-1}\end{array}$ & $\begin{array}{l}\text { Galacturonic acid } \\
\mathrm{mg} \mathrm{L}^{-1}\end{array}$ & $\begin{array}{l}\text { Glucuronic acid } \\
\mathrm{mg} \mathrm{L}^{-1}\end{array}$ \\
\hline $2390 \mathrm{EW}$ & 2.097 & 1.391 & 31.663 & 559.706 & 16.862 & 2.434 & 14.989 & 2.695 \\
$2390 \mathrm{LW}$ & 3.449 & 1.781 & 58.079 & 796.862 & 18.695 & 2.078 & 18.954 & 3.505 \\
$2547 \mathrm{EW}$ & 1.699 & 1.331 & 29.188 & 525.287 & 16.218 & 1.987 & 13.569 & 16.782 \\
$2547 \mathrm{LW}$ & 2.853 & 1.877 & 48.643 & 719.549 & 22.661 & 2.106 & 3.479 \\
\hline
\end{tabular}




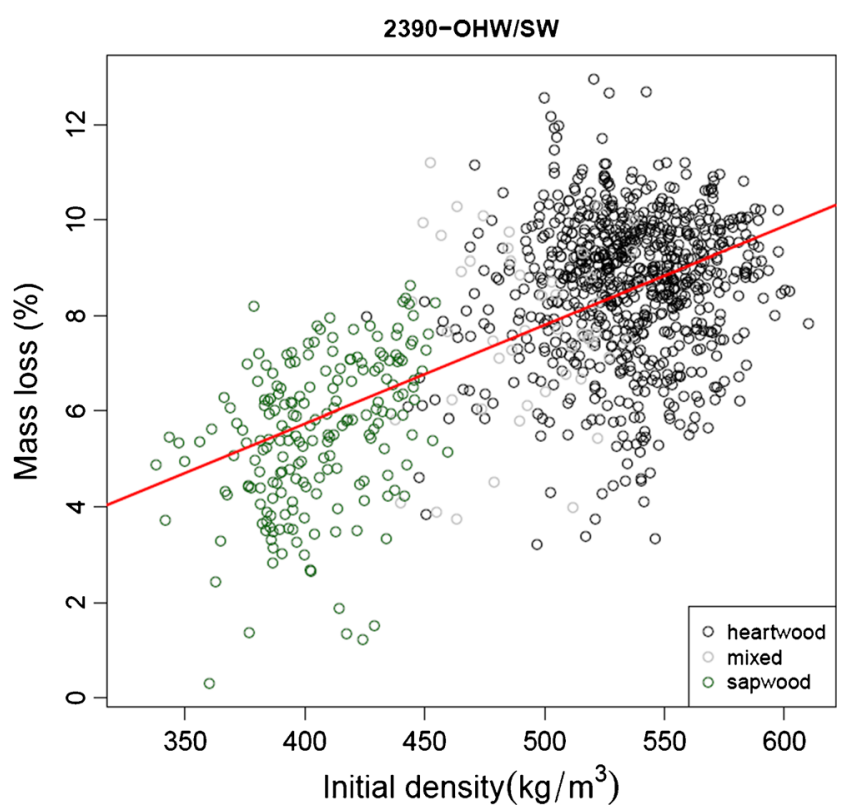

Fig. 4 Individual mass losses versus local densities recorded using X-ray $\mathrm{CT}$ recorded for board $2390 \mathrm{OHW} / \mathrm{SW}$ showing clusterization according to the origin of the point

thermo-degradation reactions explaining the higher temperature in the core compared to the edges resulting locally in a higher degradation of wood (Pétrissans et al. 2014).

\subsection{Intra-ring approach}

Even if X-ray CT is a well-recognized method to study wood density (Freyburger et al. 2009), this technique appears inappropriate within the framework of the present study to establish a clear and direct relation between initial density and thermo-degradation. X-ray CT emphasizes the high-density variability in a single board due to an inappropriate meshing unable distinguishing the ring's compartments and consequently finding a clear relation between local density and mass loss. Indeed, several studies highlight the variation of oak wood density along the radial direction according to the annual ring width and the resulting EW/LW ratio (Degron et Nepveu 1996, Guilley et al. 1999a, b; Le Moguedec et al. 2002; Guilley et Nepveu 2003, Le Moguédec et Nepveu 2004, Guilley et al. 2004). These studies show a clear difference between the densities of the earlywood and the latewood in the annual ring, which may explain the difficulties to obtain clear conclusions with X-ray CT. To evaluate the effect of earlywood and latewood densities on thermo-degradation, X-ray micro-densitometry was used to study radial wood density profiles of oak wood. Study was performed on boards obtained from two different trees (trees 2390 and 2547). Similarly to results reported in the literature (Guilley et al. 1999a, b; Le Moguedec et al. 2002; Guilley et Nepveu 2003, Knapic et al. 2007), it was found that density varies considerably during the tree growth and within a same ring,
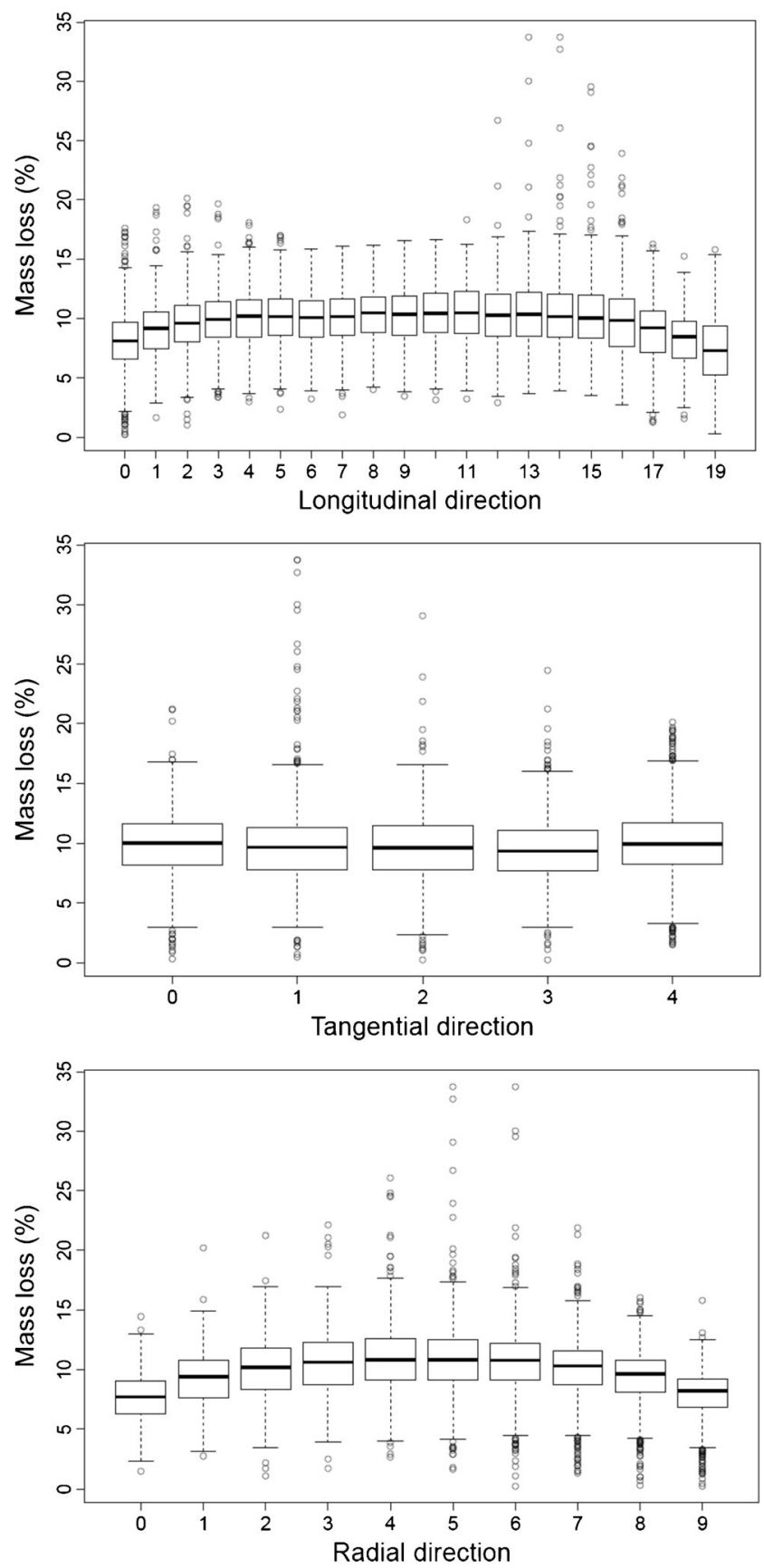

Fig. 5 Averaged mass loss distribution according to longitudinal, radial, and tangential directions of the board has been investigated using X-ray CT

earlywood presenting lower density compared to latewood (Figs. 6 and 7). Tree grown under even-aged management presents higher ring density compared to tree grown under coppice conditions (Fig. 6). Important density differences, comprised between 25 and $30 \%$, are observed between earlywood and latewood (Fig. 7). Averaged density of earlywood is considerably lower than that of latewood justifying the important variability observed by X-ray CT. To evaluate the influence of EW/LW ratio on thermo-degradation, earlywood 
Fig. 6 Variation of mean ring density (upper line) and ring width (lower line) with age from the pith to sapwood
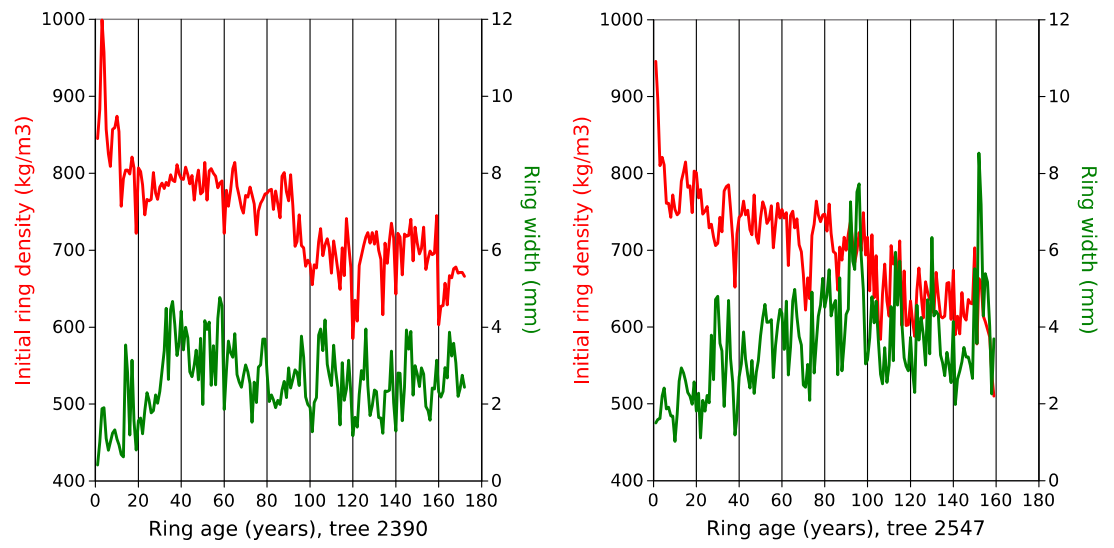

and latewood larger rings of trees 2390 and 2547 were separated, mixed together, and ground to fine sawdust before thermogravimetric analysis (Table 3). Results showed a clear difference in the thermal behavior of the earlywood and
Fig. 7 Radial density profile density for the 50 innermost rings of trees 2390 and 2547 (light blue corresponds to earlywood, dark blue to latewood)

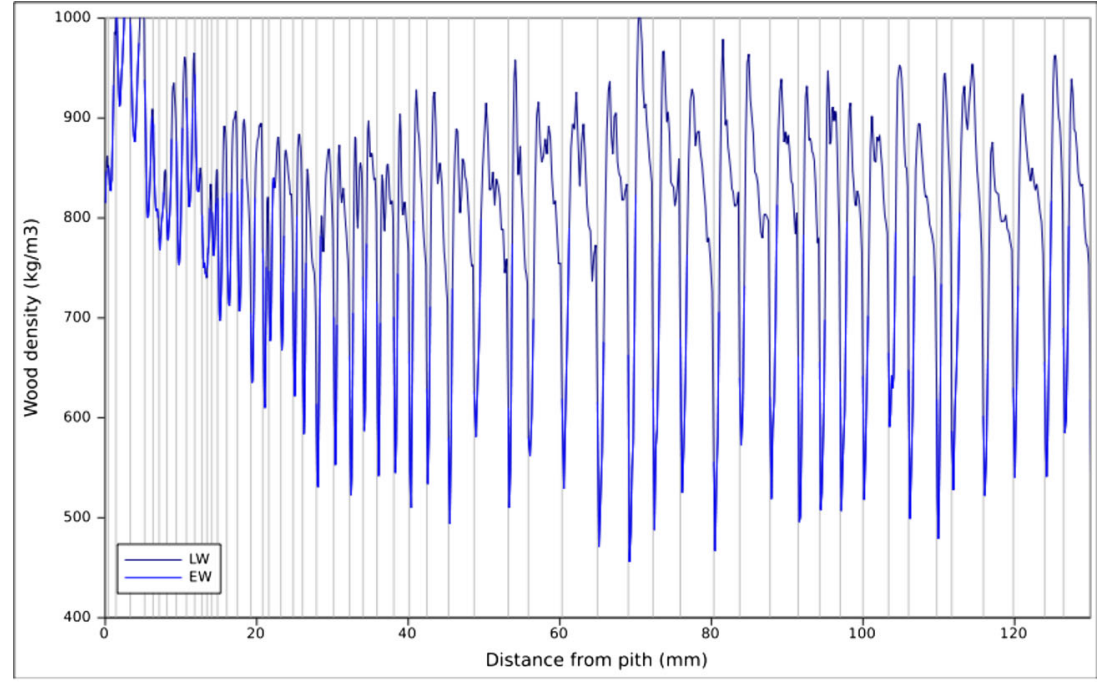

Tree 2390

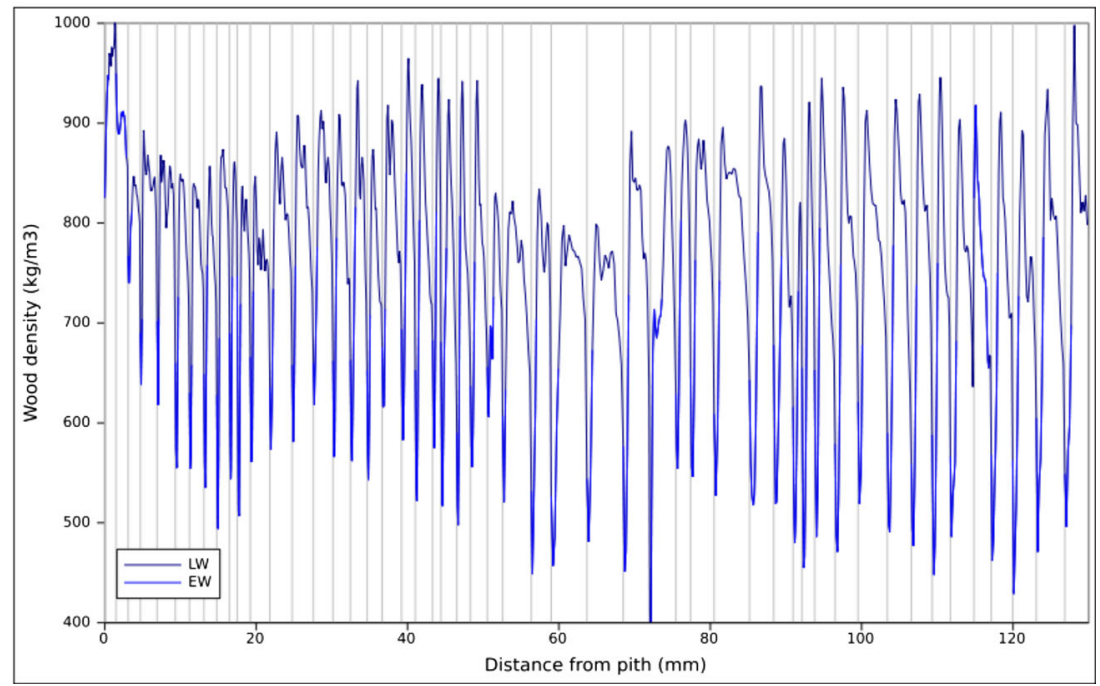

Tree 2547 
latewood compartments. For both trees studied, less dense earlywood samples were more susceptible to thermodegradation than the higher density latewood samples, when subjected to similar thermal analysis conditions. These results are in good agreement with those recently reported by Shchupakivskyy et al. (2014), showing that density of earlywood was significantly more reduced after thermal treatment than the density of latewood using high-frequency densitometry. Explanation of this difference of reactivity may be due to the anatomical and chemical structure of LW and EW compartments. Indeed, EW is known to present higher diameter vessels and thinner cell walls comparatively to LW, which presents thicker cell wall and smaller diameter vessels. Thickness of the LW cellular walls is directly connected to the thickness of the S2 layer of the secondary wall. Knowing that S2 layer is particularly rich in cellulose, it can be assumed that LW cellulose content is higher than EW cellulose content. Cellulose being less susceptible to thermal degradation than hemicelluloses and lignin (Nguila Inari et al. 2007), it seems reasonable to assume that LW is less susceptible to thermal degradation than EW. Chemical analysis performed on EW and LW samples indicated that LW contains slightly higher amounts of holocellulose than EW, which may be due to higher cellulose content (Table 3). More significantly, analysis of monosaccharide content after acidic hydrolysis (Table 4) indicates higher amounts of glucose in both LW samples confirming its higher cellulose content. These results explain also the difficulties encountered with macroscopic approach. Indeed, X-ray CT implies dividing board in small cubic volumes necessary for board cartography. Each of these volumes is constituted of different quantities of earlywood and latewood responsible for local density. Knowing that earlywood and latewood behave differently to thermal degradation, it seems logical that no clear correlation can be established with this technique. In the case of heartwood and sapwood, it has been possible to observe differences between lower density sapwood and higher density heartwood, which may be attributed to different wood chemical composition as a result of wood duraminization. According to all these results, it appears that wood quality, depending from density and ring width, is susceptible to influence wood thermal stability during industrial processes. Considering that the $\mathrm{EW} /$ LW ratio depends on numerous factors like tree age, genetics and ecology, soil quality, and forest management, it is clear that tree history can impact directly conferred properties of wood after thermal modification and especially its durability, which is directly connected to the level of degradation of wood cell wall polymers (Šušteršic et al. 2010).

\section{Conclusions}

The aim of this study was to investigate the effect of the initial variability of oak wood on its behavior during thermal treatment by mild pyrolysis. The study was carried using two approaches. The macroscopic approach at the scale board results did not allow finding a clear relation between the initial density and mass loss induced by thermal degradation. Thus, although the samples were different (averaged density ranging between 550 and $700 \mathrm{~kg} \mathrm{~m}^{-3}$ ), the averaged mass losses were quite similar (10-12\%). Emphasis was placed on the difference in thermal behavior between heartwood and sapwood, when both were present in the same board. The X-ray CT seemed to be well adapted to highlight the density variation and the mass loss heterogeneity according to longitudinal, radial, and tangential directions of the board presumably due to the thermal treatment process.

The intra-ring study allowed assessing the thermal sensitivity of both earlywood and latewood. It was observed that earlywood was more sensitive to thermal degradation than latewood. This difference of thermal reactivity is attributed to the higher cellulose content of latewood which presents larger S2 layer, rich in cellulose, in the secondary wall. Earlywood, containing more lignin and hemicelluloses than latewood, is therefore more susceptible to thermal degradation. Further studies are under consideration with softwood species to assess more deeply the behavior of the two ring compartments towards thermal degradation along the radial direction.

Acknowledgments The authors gratefully acknowledge the Région Lorraine and Lab of Excellence ARBRE for $\mathrm{PhD}$ grant of the first author. LERMAB and LERFoB are supported by a grant overseen by the French National Research Agency (ANR) as part of the "Investissements d'Avenir" program (ANR-11-LABX-0002-01, Lab of Excellence ARBRE). Authors thank warmly Charline Freyburger and Pierre Gelhaye for their technical support for X-ray CT and X-ray micro-densitometry analysis, respectively.

\section{References}

Bergès L, Nepveu G, Fanc A (2008) Effects of ecological factors on radial growth and wood density components of sessile oak (Quercus petraea Liebl.) in Northern France. For Ecol Manag 255:567-569

Bouriaud O, Breda N, Le Moguedec G, Nepveu G (2004) Modelling variability of wood density in beech as affected by ring age, radial growth and climate. Trees-Struct Funct 18:264-276

Candelier K, Chaouch M, Dumarçay S, Pétrissans A, Pétrissans M, Gérardin P (2011) Utilization of thermodesorption coupled to GCMS to study stability of different wood species to thermodegradation. J Anal App Pyrol 92:376-383

Chaouch M, Pétrissans M, Pétrissans A, Gérardin P (2010) Use of wood elemental composition to predict thermal treatment intensity and decay resistance of different softwood and hardwood species. Polym Degrad Stabil 95:2255-2259 
Degron R, Nepveu G (1996) Predicting intra- and inter-tree variability of wood density in sessile oak (Quercus petraea Liebl) through modelling earlywood and latewood width and density from cambial age, ring width and height in the tree. Ann Sci For 53:1019-1030

Freyburger C, Longuetaud F, Mothe F, Constant T, Leban JM (2009) Measuring wood density by means of X-ray computer tomography. Ann Sci For 66, 804

Guilley E, Nepveu G (2003) Anatomical interpretation of the components of a wood density mixed model in sessile oak (Quercus petraea Liebl.): ring number from the pith, ring width, tree, inter-annual variation, heartwood formation. Ann For Sci 60:331-346

Guilley E, Hervé JC, Huber F, Nepveu G (1999a) Modelling variability of within-rings density components in Quercus petraea Liebl. with mixed-effects models and simulating the influence of contrasting silvicultures on wood density. Ann Sci For 56:449-458

Guilley E, Loubere M, Nepveu G (1999b) Identification in a sessile oak forest (Quercus petraea) presenting a low wood spiral grain. Can J For Res 29:1958-1965

Guilley E, Hervé JC, Nepveu G (2004) The influence of site quality, silviculture and region on wood density mixed model in Quercus petraea Liebl. For Ecol Manag 189:111-121

Guller B (2012) Effects of heat treatment on density, dimensional stability and color of Pinus nigra wood. Afr J Biotechnol 11:2204-2209

Hakkou M, Pétrissans M, Gérardin P, Zoulalian A (2006) Investigation of the reasons for fungal durability of heat-treated beech wood. Polym Degrad Stabil 91:393-397

Kibblewhite RP, Suckling ID, Evans R, Grace JC, Riddell M (2010) Lignin and carbohydrate variation with earlywood, latewood, and compression wood content of bent and straight ramets of a radiata pine clone. Holzforschung 64:101-109

Knapic S, Louzada JL, Leal S, Pereira H (2007) Radial variation of wood density components and ring width in cork oak trees. Ann For Sci 64:211-218

Kretschmann D, Cramer SM (2007) The role of earlywood and latewood properties on dimensional stability of loblolly pine. In Proceedings of the compromised wood workshop. Christchurch, pp 215-236

Le Moguedec G, Nepveu G (2004) Using a chain of models to simulate the distribution between quality clusters of a set of boards coming from a sessile oak (Quercus petraea Liebl.) resource. Validation of the simulations. Wood Sci Technol 38:451-463

Le Moguedec G, Dhote JF, Nepveu G (2002) Choosing simplified mixed models for simulations when data have a complex hierarchical organization. An example with some basic properties in sessile oak wood (Quercus petraea Liebl.). Ann For Sci 59:847-855

Mothe F, Duchanois G, Zannier B, Leban J-M (1998a) Analyse microdensitométrique appliquée au bois : méthode de traitement des données utilisée à l'Inra-ERQB (programme CERD). Ann Sci For 1998:301-313

Mothe F, Sciama D, Leban J-M, Nepveu G (1998b) Localisation de la transition bois initial - bois final dans un cerne de chêne par analyse microdensitométrique. Ann Sci For 1998:437-449

Mouras S, Girard P, Rousset P, Permadi P, Dirol D, Labat G (2002) Propriétés physiques de bois peu durables soumis à un traitement de pyrolyse ménagée. Ann For Sci 59:317-326

Nguila Inari G, Mounguengui S, Dumarçay S, Pétrissans M, Gérardin P (2007) Evidence of char formation during heat treatment by mild pyrolysis. Polym Degrad Stabil 92:997-1002

Nguila Inari G, Pétrissans M, Pétrissans A, Gérardin P (2009) Elemental composition of wood as a potential marker to evaluate heat treatment intensity. Polym Degrad Stabil 94:365-368

Pétrissans A, Younsi R, Chaouch M, Gérardin P, Pétrissans M (2014) Wood thermodegradation: experimental analysis and modeling of mass loss kinetics. Maderas Cienc Tecnol 16:133-148

Polge H, Keller R (1973) Qualité du bois et largeur d'accroissements en forêt de Tronçais. Ann For Sci 30:91-125

R Core Team (2014) R: a language and environment for statistical computing. R Foundation for Statistical Computing, Vienna. URL http:// www.R-project.org/

Rowell RM, Pettersens R, Han JS, Rowell JS, Tshabalala MA (2005) Cell wall chemistry. In: Handbook of wood chemistry and wood composites, Taylor \& Francis, Boca Raton London New York Singapore, pp 35-72

Schneider CA, Rasband WS, Eliceiri KW (2012) NIH image to ImageJ: 25 years of image analysis. Nat Meth 9:671-675

Shchupakivskyy R, Clauder L, Linke N, Pfriem A (2014) Application of high-frequency densitometry to detect changes in early- and latewood density of oak (Quercus robur L.) due to thermal modification. Eur J Wood Prod 72:5-10

Šušteršic Ž, Mohareb A, Chaouch M, Pétrissans M, Petrič M, Gérardin P (2010) Prediction of decay resistance of heat treated wood on the basis of its elemental composition. Polym Degrad Stabil 95:94-97

Zhang S, Owoundi R, Nepveu G, Mothe F, Dhote JF (1993) Modeling wood density in European oak (Quercus petraea and Quercus robur) and simulating the silvicultural influence. Can J For Res 23:25872593 